\title{
Effect of VAM on ex vitro Hardening of Doubled Haploid Line of Marigold (Tagetes erecta L.) Variety Local Orange
}

\author{
Uzma Mehraj $^{1 *}$, Sapna Panwar ${ }^{1}$, Kanwar Pal Singh ${ }^{1}$, Namita $^{1}$ and Seema Sangwan ${ }^{2}$ \\ ${ }^{1}$ Division of Floriculture and Landscaping, ${ }^{2}$ Division of Microbiology, ICAR-Indian \\ Agricultural Research Institute, New Delhi- 110012, India \\ *Corresponding author
}

\section{Keywords \\ Tagetes erecta L., Doubled haploid line, Ex vitro hardening, VAM}

\section{Article Info}

Accepted: 10 December 2018 Available Online: 10 January 2019

\section{A B S T R A C T}

In this study, the effect of Vesicular Arbrbusular Mycorrhizae (VAM) on the ex vitro hardening of marigold was investigated. A protocol was generated for ex vitro hardening of in vitro raised plantlets using VAM consortia (Glomus intraradices, Glomus mosseae and Scutellospora spp.) in different media mixtures, and their effect was observed on plant survival and growth. Highest percent survival (94.00), maximum plant height $(39.00 \mathrm{~cm})$, maximum plant spread $(30.50 \mathrm{~cm})$, maximum stem diameter $(0.97 \mathrm{~cm})$, maximum shoot fresh weight $(0.75 \mathrm{~g})$, maximum root fresh weight $(0.46 \mathrm{~g})$, maximum leaf length $(10.27$ $\mathrm{cm})$, maximum root length $(28.50 \mathrm{~cm})$ and maximum leaf width $(6.82 \mathrm{~cm})$ were observed in treatment comprising of Soil + Vermicompost (3:1) $+20 \mathrm{~g}$ VAM consortia, Followed by $92.00 \%$ plant survival, $36.75 \mathrm{~cm}$ plant height, $29.00 \mathrm{~cm}$ plant spread, $0.81 \mathrm{~cm}$ stem diameter, $0.58 \mathrm{~g}$ shoot fresh weight, $0.45 \mathrm{~g}$ root fresh weight, $10.20 \mathrm{~cm}$ leaf length, 20.88 $\mathrm{cm}$ root length, and $6.76 \mathrm{~cm}$ leaf width in treatment comprising Soil + Vermicompost (1:1) +20 g VAM consortia. While minimum percent survival (72.50\%), lowest height (26.00 $\mathrm{cm})$, minimum plant spread $(9.50 \mathrm{~cm})$, minimum stem diameter $(0.49 \mathrm{~cm})$, minimum shoot fresh weight $(0.27 \mathrm{~g})$, minimum root fresh weight $(0.14 \mathrm{~g})$, minimum leaf length $(8.06$ $\mathrm{cm})$, minimum root length $(10.27 \mathrm{~cm})$ and minimum leaf width $(3.86 \mathrm{~cm})$ were observed in control media comprising of only soil. Followed by $85.00 \%$ survival, $29.25 \mathrm{~cm}$ plant height, $17.75 \mathrm{~cm}$ plant spread, $0.51 \mathrm{~cm}$ stem diameter, $0.34 \mathrm{~g}$ shoot fresh weight, $0.28 \mathrm{~g}$ root fresh weight, $8.07 \mathrm{~cm}$ leaf length, $14.05 \mathrm{~cm}$ root length and $4.08 \mathrm{~cm}$ leaf width were observed in media comprising of Soil + FYM (1:1) + $10 \mathrm{~g}$ VAM consortia. Highest percent colonization (60.78) was showed in media comprising of Soil + Vermicompost $(3: 1)+20 \mathrm{~g}$ VAM consortia, followed by $57.65 \%$ in media comprising of Soil + Vermicompost $(1: 1)+20 \mathrm{~g}$ VAM consortia. While lowest root colonization of $47.28 \%$ was found in media comprising of Soil + FYM $(1: 1)+10 \mathrm{~g}$ VAM consortia followed by $50.37 \%$ in media comprising of Soil+ FYM (3:1) +10 g VAM consortia. Control treatment, without any VAM added, showed no root colonization. Hence, it was concluded that the treatment with a mixture of Soil + Vermicompost (3:1) with $20 \mathrm{~g}$ VAM consortia showed the best results in various aspects. 


\section{Introduction}

Marigold (Tagetes spp.) is one of the most important flower crop known globally for its ornamental and medicinal values. It is an important member of Asteraceae family and native to South and Central America (Mexico). Genus Tagetes is reported of comprising of approximately 55 species (Godoy-Hernandez and Miranda-Ham, 2007), out of which, Tagetes erecta L. (African marigold) and Tagetes patula L. (French marigold) are of commercial importance. In India, marigold ranks first in area and production of loose flower crops, being cultivated in an area of 66.13 thousand hectares with the production of 603.18 thousand metric tons (Anonymous, 2017) and is grown almost throughout the country. It is gaining popularity among flower growers. The major drawback of in vivo propagation is lack of sufficient plant material for large scale multiplication and season bound nature of the activity. Hence, to overcome such limitations, in vitro mass multiplication is one of the best options to obtain maximum population of doubled haploids under short span of time. The advantage of in vitro multiplication of doubled haploids is that large number of quality regenerants per explant can be obtained and moreover, it is a year round activity.

In vitro multiplication of doubled haploids has been successfully done in crops like tall fescue (Kasperbaeur and Eizenga, 1985); sugar beet (Magdalena and Baranski, 2013) etc. The use of doubled haploids developed through tissue culture drastically reduces the time for precise and efficient selection for desirable traits. Ex vitro evaluation is essential to know the stability and performance of doubled haploids at field level. Moreover, the conditions to which micropropagated plantlets are transferred from in vitro conditions to which they are accustomed to distinct in vivo conditions would be a kind of stress (popularly referred to as transplantation shock) to them.

Weak root system is one of the major hindrances in the successful establishment of the micropropagated plantlets in the field conditions. In general, mycorrhizal fungi help in the development of a stronger root system (Ponton et al., 1990). Some plants exhibit considerable dependence on mycorrhizae to thrive in stressed situations (Barea et al., 1993; Bethlenfalvay et al., 1987).

These potentials of symbiotic association between VAM (Vesicular Arbuscular Mycorrhiza) fungal species and plant roots strengthen the belief of its significance in averting the transplantation shock brought about by unfavorable environmental conditions (such as alteration in humidity and nutritional conditions). VAM is a fungus that penetrates the roots of a vascular plant in order to help them to capture nutrients from the soil. These fungi are scientifically well known for their ability to uptake and transport mineral nutrients from the soil directly into host plant roots. The main beneficial effects reported are the avoidance of transplanting shock, shorter weaning phase (Salamanca et al., 1992), higher plant growth variants. Micropropagated plants usually have weak stomatal control.

Inoculating these plants with symbiotic fungi leads to the production of lipids and abscissic acid which are responsible for the control of rate of transpiration. Moreover, AMF (Arbuscular Mycorrhizal Fungi) colonization of plants can improve growth by increasing the uptake of phosphorus, zinc and other minerals, reducing disease, increasing transplanting uniformity by increasing survival percentage, improving water relations of the host plant and increasing drought resistance. 


\section{Materials and Methods}

\section{Plant material}

The source of explant was the doubled haploid line of African marigold variety Local Orange developed through ovule culture. The plants of the doubled haploid line were maintained under net house conditions at the farm of the Division of Floriculture and Landscaping, ICAR- Indian Agricultural Research Institute, New Delhi. The basal portion of leaf was used as explants. After regenerating, the micro shoots were given rooting and in vitro hardening treatments and after maintaining the raised plantlets under in vitro conditions, they were taken out for ex vitro hardening treatments.

\section{Ex vitro hardening}

The in vitro hardened plants after being taken outside were hardened under ex vitro conditions using VAM consortia. The VAM consortia containing mixture of Glomus intraradices, Glomus mosseae and Scutellospora spp. were used to observe their effect on plant survival and growth. The earthen pots of eight inches size were used for growing the plants. The quantity of soil, FYM and vermicompost were measured on the basis of volume in 8 inch pots $(\mathrm{v} / \mathrm{v})$. Different potting mixtures used with different VAM consortia are given in table 1 . The experiment was carried out in completely randomized design (CRD) with four replications. Each replication consists of 20 plants.

\section{Observations recorded}

Survival of plantlets and association with AMF

Per cent survival was recorded on the basis of number of plants survived out of total number of plants kept for hardening.

\section{Per cent root colonization was calculated by the following procedure}

Clearing and staining root specimens For Clearing and staining procedures root samples were washed free of soil and then chopped in to smaller $(1-2 \mathrm{~cm})$ segments.

Root specimens stored in capsules, were washed under running tap water thoroughly. The root samples were then placed in a beaker containing 5-10\% KOH solution for about 15 30 minutes. The concentration of $\mathrm{KOH}$ and time of incubation of roots varies as per the age and tenderness of the roots.

$\mathrm{KOH}$ solution was poured off and the capsules were rinsed well in a beaker using at least three complete changes of tap water or until no brown colour appears in the rinsed water.

The capsules were covered in the beaker with alkaline $\mathrm{H} 2 \mathrm{O} 2$ at room temperature for 10 minutes or until roots were bleached.

The capsules were rinsed in the beaker thoroughly using at least three complete changes of tap water to remove the $\mathrm{H} 2 \mathrm{O} 2$.

The capsules were covered in the beaker with $1 \% \mathrm{HCl}$ and soaked for 3-4 minutes and then the solution was poured off. Rinsing was not done after this because the specimens must be acidified for proper staining.

The capsules were covered in the beaker with staining solution $(0.01 \%$ acid fuchsin in lactoglycerol or $0.05 \%$ trypan blue in lactophenol) and kept overnight for staining.

After removing from the capsules, the root specimens were placed in glass petri plate /multi-well plate for destaining. The destaining solution $(50 \%$ glycerol) is the standard used in step 6, but without the stain. 
Sample storage and slide preparation stained roots were observed in plain lactoglycerol on a temporary slide (Figure 1).

\section{Growth parameters}

The various growth parameters were recorded on the basis of average plant height of 20 plants that survived in each treatment after 15 , 30 and 45 days. The various parameters recorded are plant height $(\mathrm{cm})$, plant spread $(\mathrm{cm})$, Stem diameter $(\mathrm{cm})$, Shoot fresh weight $(\mathrm{g})$, Root fresh weight $(\mathrm{g})$, Root length $(\mathrm{cm})$, Leaf length $(\mathrm{cm})$, Leaf width $(\mathrm{cm})$.

\section{Data analysis}

The experiments were laid out in completely randomized design (CRD). Each treatment had 20 units and with four replications. Each experiment was repeated at least twice and the reported data are the means of two experiments. Wherever applicable the data are presented as mean \pm standard error. All the percentage data was subjected to angular transformation before calculating ANOVA.

\section{Results and Discussion}

\section{Per cent survival $(\%)$}

From the experiment, it was concluded that highest per cent survival (94.00) was found in treatment with Soil + Vermicompost (3:1) + $20 \mathrm{~g}$ VAM consortia followed by $92.00 \%$ survival in treatments with Soil + Vermicompost $(1: 1)+20$ g VAM consortia and treatment with Soil + FYM (3:1) + $20 \mathrm{~g}$ VAM consortia, While minimum percent survival was observed as $(72.50 \%)$ in control treatment (with soil only), followed by $85.00 \%$ survival in treatment with Soil + FYM $(1: 1)+10$ g VAM consortia (Table 2).

\section{Per cent root colonization}

It was observed that highest per cent colonization (60.78) was observed in treatment with Soil + Vermicompost (3:1) +
20 g VAM consortia, followed by $57.65 \%$ in treatment with Soil + Vermicompost $(1: 1)+$ $20 \mathrm{~g}$ VAM consortia and $54.95 \%$ in treatment with Soil + FYM (3:1) + 20 g VAM consortia. While the lowest root colonization of $47.28 \%$ was found in treatment with Soil + FYM (1:1) $+10 \mathrm{~g}$ VAM consortia followed by $50.37 \%$ in treatment with Soil+ FYM (3:1) +10 g VAM consortia. Control treatment without any VAM added showed no root colonization (Table 2).

\section{Plant height (cm)}

It was observed that highest plant height $(39.00 \mathrm{~cm})$ was observed in treatment with Soil + Vermicompost $(3: 1)+20$ g VAM consortia, followed by $36.75 \mathrm{~cm}$ plant height in treatment with Soil + Vermicompost (1:1) + $20 \mathrm{~g}$ VAM consortia and $35.75 \mathrm{~cm}$ plant height in treatment with Soil + FYM (3:1) + $20 \mathrm{~g}$ VAM consortia. While the lowest height $(26.00 \mathrm{~cm})$ was found in treatment with only soil (control) followed by $29.25 \mathrm{~cm}$ plant height in treatment with Soil + FYM (1:1) + $10 \mathrm{~g}$ VAM consortia (Table 2).

\section{Plant spread (cm)}

It was concluded that maximum plant spread $(30.50 \mathrm{~cm})$ was found in treatment with Soil + Vermicompost $(3: 1)+20$ g VAM consortia, followed by $29.00 \mathrm{~cm}$ plant spread in treatment with Soil + Vermicompost $(1: 1)+$ $20 \mathrm{~g}$ VAM consortia and $23.25 \mathrm{~cm}$ plant spread in treatment with Soil + FYM (3:1) + $20 \mathrm{~g}$ VAM consortia. While the minimum plant spread $(9.50 \mathrm{~cm})$ was observed in treatment with only soil (control) followed by $17.75 \mathrm{~cm}$ plant spread in treatment with Soil + FYM (1:1) + 10 g VAM consortia (Table 2).

\section{Stem diameter $(\mathrm{cm})$}

It was observed that maximum stem diameter $(0.97 \mathrm{~cm})$ was found in treatment with Soil + Vermicompost $(3: 1)+20$ g VAM consortia, 
followed by $0.81 \mathrm{~cm}$ stem diameter in treatment with Soil + Vermicompost (1:1) + $20 \mathrm{~g}$ VAM consortia and 0.77 stem diameter in treatment with Soil + FYM (3:1) + $20 \mathrm{~g}$ VAM consortia. While minimum stem diameter $(0.49 \mathrm{~cm})$ was observed in treatment with only soil (control) followed by $0.51 \mathrm{~cm}$ stem diameter in treatment with Soil + FYM $(1: 1)+10 \mathrm{~g}$ VAM consortia. Data showed that all the treatments were significantly different over control, with soil only (Table 2 ).

\section{Shoot fresh weight $(g)$}

It was observed that maximum fresh weight of shoot $(0.75 \mathrm{~g})$ was found in treatment with Soil + Vermicompost $(3: 1)+20$ g VAM consortia, followed by $0.58 \mathrm{~g}$ shoot fresh weight in treatment with Soil + Vermicompost $(1: 1)+20 \mathrm{~g}$ VAM consortia and $0.57 \mathrm{~cm}$ shoot fresh weight in treatment with Soil + FYM (3:1) + 20 g VAM consortia.. While the minimum shoot fresh weight $(0.27 \mathrm{~g})$ was found as in treatment with only soil (control) followed by $0.34 \mathrm{~g}$ shoot fresh weight in treatment with Soil + FYM (1:1) + 10 g VAM consortia (Table 2).

\section{Root fresh weight (g)}

It was observed that maximum root fresh weight $(0.46 \mathrm{~g})$ was observed in treatment with Soil + Vermicompost $(3: 1)+20$ g VAM consortia, followed by $0.45 \mathrm{~g}$ root fresh weight in treatment with Soil + Vermicompost $(1: 1)+20 \mathrm{~g}$ VAM consortia and $0.42 \mathrm{~g}$ root fresh weight in treatment with Soil + FYM $(3: 1)+20$ g VAM consortia. While minimum root fresh weight $(0.14 \mathrm{~g})$ was found as in treatment with only soil (control) followed by $0.28 \mathrm{~g}$ root fresh weight in treatment with Soil + FYM (1:1) + 10 g VAM consortia (Table 2).

\section{Leaf length (cm)}

It was observed that maximum leaf length
$(10.27 \mathrm{~cm})$ was observed in treatment with Soil + Vermicompost $(3: 1)+20$ g VAM consortia, followed by $10.20 \mathrm{~cm}$ leaf length in treatment with Soil + Vermicompost $(1: 1)+$ $20 \mathrm{~g}$ VAM consortia and treatment with Soil + FYM (3:1) + 20 g VAM consortia. While minimum leaf length $(8.06 \mathrm{~cm})$ was observed in treatment with only soil (control) followed by $8.07 \mathrm{~cm}$ leaf length in treatment with Soil + FYM (1:1) + 10 g VAM consortia (Table 2).

\section{Root length (cm)}

It was observed that maximum root length $(28.50 \mathrm{~cm})$ was observed in treatment with Soil + Vermicompost $(3: 1)+20$ g VAM consortia, followed by $20.88 \mathrm{~cm}$ root length in treatment with Soil + Vermicompost $(1: 1)+$ $20 \mathrm{~g}$ VAM consortia and $15.47 \mathrm{~cm}$ root length in treatment with Soil + FYM (3:1) + $20 \mathrm{~g}$ VAM consortia. While minimum root length $(10.27 \mathrm{~cm})$ was observed in treatment with only soil (control) followed by $14.05 \mathrm{~cm}$ root length in treatment with Soil + FYM (1:1) + $10 \mathrm{~g}$ VAM consortia (Table 2).

\section{Leaf width $(\mathrm{cm})$}

It was observed that maximum leaf width $(6.82 \mathrm{~cm})$ was found in treatment with Soil + Vermicompost $(3: 1)+20$ g VAM consortia, followed by $6.76 \mathrm{~cm}$ leaf width in treatment with Soil + Vermicompost (1:1) + 20 g VAM consortia and $6.43 \mathrm{~cm}$ leaf width in treatment with Soil + FYM (3:1) + 20 g VAM consortia. While minimum leaf width $(3.86 \mathrm{~cm})$ was observed in treatment with only soil (control) followed by $4.08 \mathrm{~cm}$ leaf width in treatment with Soil + FYM (1:1) + 10 g VAM consortia (Table 2). Micropropagation has been extensively used for the rapid multiplication of many plant species. However, its wider use is restricted often by the high percentage of plant loss when transferred to ex vitro conditions. This is due to the fact that regenerant has to adjust to varied abnormalities in ex vitro 
environments viz., high irradiance level, low humidity, limiting water due to low hydraulic conductivity of roots and root system connections. Acclimatization of regenerates will overcome this problem with gradual lowering in air humidity (Bolar et al., 1998; Lavanya et al., 2009).

The ultimate success of in vitro propagation lies in the successful establishment of plants in the soil (Saxena and Dhawan, 1999). To acclimatize the micropropagated plants, different workers have employed different approaches towards successful establishment. VAM is reported to increase the surface area for nutrient absorption and hence, helps in acclimatization; hence, present study was aimed to develop an efficient acclimatization technique using VAM for in vitro raised plants.

The role of arbuscular mycorrhizal fungi (AMF) in acclimatization has been exploited with success.

Arbuscular-mycorrhizal fungi (AMF) have been successfully used to improve acclimatization, survival and growth of many micropropagated fruit species (Lovato et al., 1996) such as pistachios (Schubert and Martinelli, 1988), pineapple (Guillemin et al., 1992), apple (Branzanti et al., 1992; Sbrana et al., 1994), pear and peach (Rapparini et al., 1994), and Prunus rootstocks (Estaun et al., 1994; Estaun et al., 1999).

In the present study, different hardening media with different concentrations of VAM were tested of which treatment with Soil + Vermicompost $(3: 1)+20$ g VAM consortia was found best.

Other workers also observed the similar results as Arbuscular mycorrhizal fungi (AMF) form symbiotic association with plant roots and are involved in plant nutrient uptake, growth and tolerance to environmental stresses (Fitter and Moyersoen, 1996; Smith and Read, 1997). The studies conducted by Chitra (2014) on sesame and sorghum plants showed a significant improvement in plant growth due to vermicompost amendments. The length and leaf surface area increased considerably in the vermicompost treated plants.

The growth response of these plants was superior which in turn enhanced soil nutrients and microbial population. The study also established that the association of VAM fungi with sesame and sorghum enhanced the growth when compared with control. Mehraban et al., (2009) showed significant differences between cultivars of sorghum and using mycorrhiza on plant height, number of seed in spike, biomass, and root colonization.

Gupta et al., (2002) concluded that the VAM inoculation could significantly increase the root colonization, growth, essential oil yield and nutrient acquisition of mint for obtaining economic production under field conditions.

Experiments conducted by Azkon-Aguilar et al., (1992) on avocado, showed that survival of plantlets was highest in a soil - sand substratum and was increased by inoculation with Glomus sp. in a peat - perlite mix. They also observed that Mycorrhizal infection by Glomus sp during the acclimatization process improved development of micropropagated avocado plants.

Their experiments also revealed that inoculation with other AM fungi showed that Glomus deserticola, and to a lesser extent Glomus mosseae, improved plant development in the soil - sand mix. Hence, they concluded that Mycorrhiza formation appears to play a key role in favouring ex vitro development of micropropagated plants of avocado. 
Table.1 Effect of VAM inoculation on ex vitro establishment and morphological parameters of in vitro raised plantlets of doubled haploid line of African marigold variety Local Orange

\begin{tabular}{|c|c|c|c|c|c|c|c|c|c|}
\hline Treatment (s) & $\begin{array}{l}\text { Percent } \\
\text { survival }(\%)\end{array}$ & $\begin{array}{l}\text { Plant } \\
\text { height }(\mathrm{cm})\end{array}$ & $\begin{array}{l}\text { Plant } \\
\operatorname{spread}(\mathrm{cm})\end{array}$ & $\begin{array}{l}\text { Stem } \\
\text { diameter } \\
(\mathrm{cm})\end{array}$ & $\begin{array}{l}\text { Shoot fresh } \\
\text { weight }(g)\end{array}$ & $\begin{array}{l}\text { Root } \\
\text { fresh } \\
\text { weight (g) }\end{array}$ & $\begin{array}{l}\text { Leaf length } \\
\text { (cm) }\end{array}$ & $\begin{array}{l}\text { Root length } \\
\text { (cm) }\end{array}$ & $\begin{array}{l}\text { Leaf width } \\
\text { (cm) }\end{array}$ \\
\hline $\mathbf{T}_{0^{-}}$Soil only(control) & $\begin{array}{c}72.50 \\
(58.37) * \pm 1.44\end{array}$ & $26.00 \pm 1.08$ & $9.50 \pm 1.85$ & $0.49 \pm 0.01$ & $0.27 \pm 0.03$ & $0.14 \pm 0.03$ & $8.06 \pm 0.02$ & $10.27 \pm 0.11$ & $3.86 \pm 0.05$ \\
\hline $\begin{array}{l}\mathrm{T}_{1}-\text { Soil }+ \text { FYM }(1: 1)+10 \\
\text { g VAM consortia }\end{array}$ & $\begin{array}{c}85.00 \\
(67.33) \pm 2.04\end{array}$ & $29.25 \pm 3.68$ & $17.75 \pm 2.56$ & $0.51 \pm 0.01$ & $0.34 \pm 0.02$ & $0.28 \pm 0.03$ & $8.07 \pm 0.09$ & $14.05 \pm 0.06$ & $4.08 \pm 0.01$ \\
\hline $\begin{array}{l}T_{2^{-}} \text {Soil + FYM }(1: 1)+20 \\
\text { g VAM consortia }\end{array}$ & $\begin{array}{c}91.87 \\
(73.46) \pm 0.83\end{array}$ & $33.25 \pm 1.31$ & $20.25 \pm 3.42$ & $0.74 \pm 0.02$ & $0.53 \pm 0.02$ & $0.34 \pm 0.02$ & $10.18 \pm 0.07$ & $15.21 \pm 0.07$ & $6.30 \pm 0.04$ \\
\hline $\begin{array}{l}\text { T}_{3}-\text { Soil }+ \text { FYM }(3: 1)+ \\
10 \text { g VAM consortia }\end{array}$ & $\begin{array}{c}90.87 \\
(72.41) \pm 0.55\end{array}$ & $29.5 \pm 0.29$ & $18.25 \pm 1.25$ & $0.64 \pm 0.02$ & $0.36 \pm 0.02$ & $0.24 \pm 0.02$ & $8.15 \pm 0.058$ & $14.57 \pm 0.19$ & $4.44 \pm 0.03$ \\
\hline $\begin{array}{l}T_{4}-\text { Soil }+ \text { FYM }(3: 1)+ \\
20 \text { g VAM consortia }\end{array}$ & $\begin{array}{c}92.00 \\
(73.62) \pm 0.91\end{array}$ & $35.75 \pm 4.62$ & $23.25 \pm 2.69$ & $0.77 \pm 0.03$ & $0.57 \pm 0.03$ & $0.42 \pm 0.01$ & $10.20 \pm 0.03$ & $15.47 \pm 0.05$ & $6.43 \pm 0.02$ \\
\hline $\begin{array}{l}T_{5}-\text { Soil+ Vermicompost } \\
(1: 1)+10 g \text { VAM } \\
\text { consortia }\end{array}$ & $\begin{array}{c}91.50 \\
(73.10) \pm 0.96\end{array}$ & $34.75 \pm 2.46$ & 18.751 .11 & $0.65 \pm 0.02$ & $0.36 \pm 0.02$ & $0.30 \pm 0.02$ & $9.41 \pm 0.20$ & $15.19 \pm 1.10$ & $5.30 \pm 0.01$ \\
\hline $\begin{array}{l}T_{6}-\text { Soil + Vermicompost } \\
(1: 1)+20 \text { g VAM } \\
\text { consortia }\end{array}$ & $\begin{array}{c}92.00 \\
(73.62) \pm 0.91\end{array}$ & $36.75 \pm 2.29$ & $29.00 \pm 3.03$ & $0.81 \pm 0.02$ & $0.58 \pm 0.02$ & $0.45 \pm 0.01$ & $10.20 \pm 0.03$ & $20.88 \pm 0.10$ & $6.76 \pm 0.06$ \\
\hline $\begin{array}{l}T_{7} \text { - Soil + Vermicompost } \\
(3: 1)+10 g \text { VAM } \\
\text { consortia }\end{array}$ & $\begin{array}{c}91.75 \\
(73.31) \pm 0.63\end{array}$ & $30.75 \pm 0.48$ & $19.25 \pm 0.48$ & $0.72 \pm 0.01$ & $0.40 \pm 0.02$ & $0.31 \pm 0.01$ & $9.46 \pm 0.03$ & $15.20 \pm 0.11$ & $5.48 \pm 0.07$ \\
\hline $\begin{array}{l}T_{8}-\text { Soil + Vermicompost } \\
(3: 1)+20 \mathrm{~g} \text { VAM } \\
\text { consortia }\end{array}$ & $\begin{array}{c}94.00 \\
(76.02) \pm 1.35\end{array}$ & $39.00 \pm 5.28$ & $30.50 \pm 0.29$ & $0.97 \pm 0.02$ & $0.75 \pm 0.02$ & $0.46 \pm 0.04$ & $10.27 \pm 0.11$ & $28.50 \pm 0.28$ & $6.82 \pm 0.31$ \\
\hline$\pm \mathrm{SE}(\mathrm{m})$ & 1.21 & 2.93 & 2.14 & 0.02 & 0.02 & 0.02 & 0.09 & 0.14 & 0.04 \\
\hline C.D. $(P \leq 0.05)$ & 3.54 & N/A & 6.24 & 0.05 & 0.07 & 0.07 & 0.26 & 0.40 & 0.12 \\
\hline
\end{tabular}

*Values in parenthesis are angular values 
Table.2 Effect of VAM inoculation on root colonisation (percentage) in roots of in vitro raised plantlets of doubled haploid line of African marigold variety Local Orange

\begin{tabular}{|l|c|}
\hline Treatment (s) & $\begin{array}{c}\text { Roots Colonisation (\%) by } \\
\text { AMF }\end{array}$ \\
\hline $\mathrm{T}_{0}$ - control, soil only & 0.00 \\
\hline $\mathrm{T}_{1}$ - Soil + FYM $(1: 1)+10 \mathrm{~g}$ VAM consortia & $(0.00) \pm 0.00$ \\
\hline $\mathrm{T}_{2}$ - Soil + FYM $(1: 1)+20 \mathrm{~g}$ VAM consortia & 47.28 \\
& $(43.43) \pm 0.82$ \\
\hline $\mathrm{T}_{3}$ - Soil + FYM $(3: 1)+10 \mathrm{~g}$ VAM consortia & 54.90 \\
& $(47.79) \pm 0.93$ \\
\hline $\mathrm{T}_{4}$ - Soil + FYM $(3: 1)+20 \mathrm{~g}$ VAM consortia & 50.37 \\
& $(45.20) \pm 0.79$ \\
\hline $\mathrm{T}_{5}$ - Soil+ Vermicompost $(1: 1)+10 \mathrm{~g}$ VAM consortia & 54.95 \\
& $(47.82) \pm 0.60$ \\
\hline $\mathrm{T}_{6}$ - Soil + Vermicompost $(1: 1)+20$ g VAM consortia & 51.33 \\
& $(45.74) \pm 1.24$ \\
\hline $\mathrm{T}_{7}$ - Soil + Vermicompost $(3: 1)+10 \mathrm{~g}$ VAM consortia & 57.65 \\
\hline $\mathrm{T}_{8}$ - Soil + Vermicompost $(3: 1)+20$ g VAM consortia & $(49.38) \pm 0.33$ \\
\hline \pm SE(m) & 54.62 \\
\hline C.D. $(\mathbf{P} \leq \mathbf{0 . 0 5})$ & $(47.63) \pm 0.32$ \\
\hline
\end{tabular}

Fig.1 Root infection by VAM species (Glomus intraradices, Glomus mosseae and Scutellospora sp.)

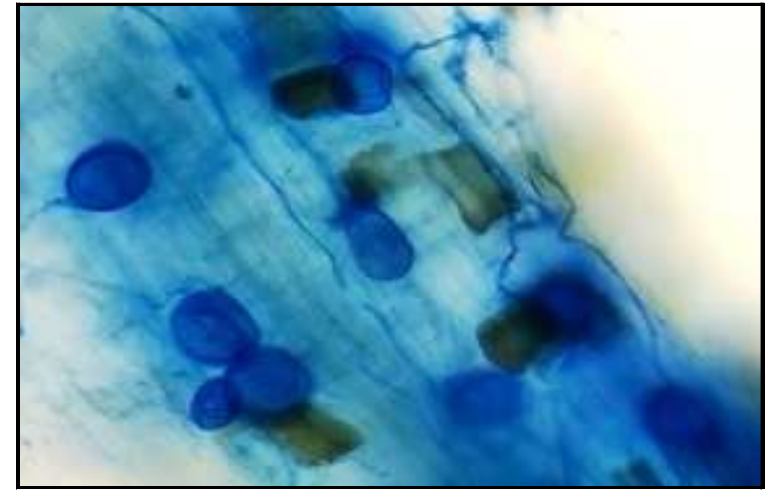

Vesicular growth of AMF

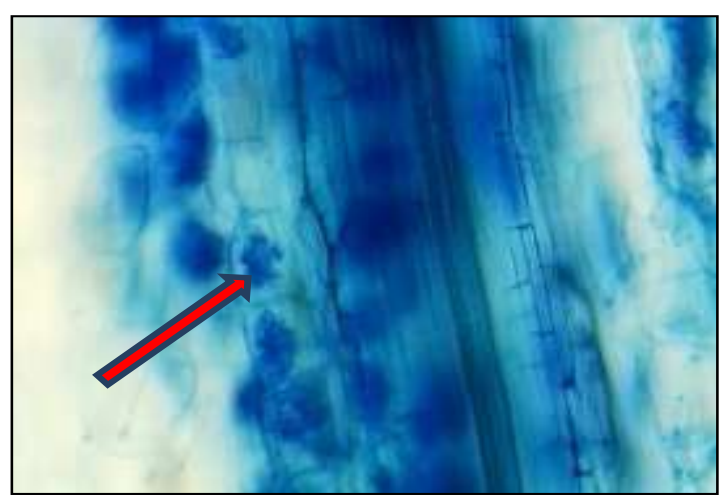

Arbuscular growth of AMF 


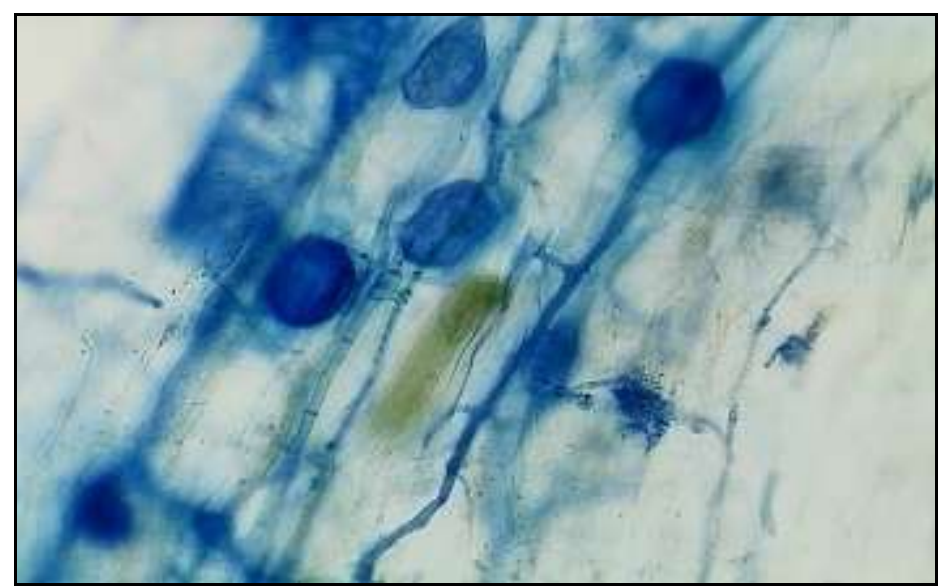

Hyphae of AMF

The effect of arbuscular mycorrhizal fungi (AMF) on micropropagated banana plantlets was evaluated by Yano-Melo et al., (1999) during the acclimatization period. They inoculated the Plants with Acaulospora scrobiculata, Glomus clarum or Glomus etunicatum. After cultivation in a greenhouse for 3 months, they measured the height, leaf area, fresh weight and dry matter of root and shoots, level of AMF colonization, nutrient level, photosynthesis and transpiration rate, water potential and stomatal conductance. They found that the plantlets inoculated with AMF had greater height, leaf area and fresh weight of shoots and roots, as well as higher rates of photosynthesis and transpiration than controls. They concluded that the plants inoculated with Glomus were superior in most of the evaluated parameters. Further, Wang et al., (1993) did their experiments on micropropagated plantlets of Gerbera jamesonii, Nephrolepis exaltata and Syngonium podophyllum, in which they were inoculated with two vesicular-arbuscular mycorrhizal (VAM) fungi, Glomus intraradices Glomus vesiculiferum Gerderman. They observed that mortality of Gerbera and Nephrolepis mycorrhizal plantlets was reduced at week 8 compared to the non-inoculated control. They also found that mycorrhizal substrates had a long term benefit of increasing leaf and root dry weight of Gerbera and Nephrolepis and that
Mycorrhizal Gerbera plants flowered significantly faster than non-mycorrhizal plants.

\section{References}

Anonymous. (2017). Indian Horticulture Database. (Online) Available Online at http://nhb.gov.in.

Azcón-Aguilara, C., Barcelób, A., Vidala, M. T. and de la Viñab G. (1992). Further studies on the influence of mycorrhizae on growth and development of micropropagated avocado plants. Agronomie. 12: 837840.

Barea, J. M., Azcón, R. and Azcón-Aguilar C. (1993). Mycorrhiza and crops. Advances on Plant Pathology. 9:167189.

Bethlenfalvay, G. J., Brown, M. S., Mihara, K. L. and Stafford, A. E. (1987). Glycine- Glomus-Rhizobium Symbiosis V, Effects of mycorrhiza on nodule activity and transpiration in soyabeans under drought stress. Plant Physiology. 85: 115-119.

Bolar, J. P., Norelli, J. L., Aldwinckle, H. S. and Hanke, V. (1998). An efficient method for rooting and acclimation of micropropagated apple cultivars. HortScience. 37: 1251-1252.

Branzanti, B., Gianinazzi-Pearson, V. and 
Gianinazzi, S. (1992). Influence of phosphate fertilization on the growth and nutrient status of micropropagated apple infected with endomycorrhizal fungi during the weaning stage. Agronomie. 12: 841-846.

Chitra, K. (2014). Infectivity and effectiveness of VAM on sesame and Sorghum plants. International Journal of Current Microbiology and Applied Sciences. 4: 1022-1027

Estaún, V., Calvet, C., Camprubí, A. and Pinochet, J. (1999). Long-term effects of nursery starter substrate and AM inoculation of micropropagated peach $\times$ almond hybrid rootstock GF 677 . Agronomie. 19: 483-489.

Estaun, V., Calvet, C. and Camprubi, A. (1994). Arbuscular mycorrhizae and growth enhancement of micropropagated prunus rootstock in different soilless potting mixes. Agricultural Science in Finland. 3: 263-267.

Fitter, A. H. and Moyersoen, B. (1996). Evolutionary trends in rootmicrobe symbioses. Philosophical Transactions of the Royal Society of London Series B. 351: 1367-1375.

Godoy-Hernandez, G. and Miranda-Ham, M. L. (2007). Marigold biotechnology: Tissue culture and genetic transformation. Transgenic Plant Journal. 1: 169-174.

Guillemin, J. P., Gianinazzi, S. and Trouvelot, A. (1992). Screening of arbuscular endomycorrhizal fungi for establishment of micropropagated pineapple plants. Agronomie. 12: 831836.

Gupta, M. L., Prasad, A., Ram, M. and Kumar, S. (2002). Effect of the vesicular-arbuscular mycorrhizal (VAM) fungus Glomus fasciculatum on the essential oil yield related characters and nutrient acquisition in the crops of different cultivars of menthol mint (Menthaarvensis) under field conditions. Bioresource Technology. 81(1): 77-9.

Kasperbauer, M. J. and Eizenga, G. C. (1985). Tall Fescue doubled haploids via tissue culture and plant regeneration. Crop Science. 25: 1091-1095.

Lavanya, M., Venkateshwarlu, B. and Devi, B. P. (2009). Acclimatization of neem micro shoots adaptable to semi-sterile conditions. Indian Journal of Biotechnology. 8: 218-222

Lovato, P. E., Gianinazzi-Pearson,V., Trouvelot, A. and Gianinazzi, S. (1996). The state of art of mycorrhizas and micropropagation. Advances in Horticultural science. 10: 46-52

Magdalena, Klimek-Chodacka, Rafal and Baranski. (2013). Comparison of haploid and doubled haploid sugar beet clones in their ability to micropropagate and regenerate. Electronic Journal of Biotechnology. 16(2): 0717-3458

Mehraban, A., Vazan, S., Naroui, Rad, M. R. and Ardakany, A. R. (2009). Effect of vesicular-arbuscular mycorrhiza (VAM) on yield of sorghum cultivars. Journal of Food, Agriculture \& Environment. 7: 461-463.

Ponton, F., Piche, Y., Parent, S. and Caron, M. (1990). The use of Vesicular arbuscular mycorrhizae in boston fern production: I. Effect ofpeat-based mixes. HortScience. 25: 183-189.

Rapparini, F., Baraldi, R., Bertazza, B., Branzanti, B. and Predieri, S. (1994). Vesicular arbuscular mycorrhizal inoculation of micropropagated fruit tree. Journal of Horticultural Science. 69: 1101-1109.

Salamanca, C. P., Harrea, M. A. and Barea, J. M. (1992). Mycorrhizal inoculation of micropropagated woody legumes used in revegetation programmes for 
desertified Mediterranean ecosystems. Agronomie. 12: 869-87

Saxena, S. and Dhawan, B. (1999). Regeneration and large-scale propagation of bamboo (Dendrocalamus strictus Nees) through somatic embryogenesis. Plant Cell Reports. 18: 438-443.

Sbrana, C., Giovannetti, M. and Vitagliano, C. (1994). The effect of mycorrhizal infection on survival and growth renewal of micropropagated fruit rootstocks. Mycorrhiza. 5:153-156.

Schubert, A. and Martinelli, A. (1988). Effect of vesicular-arbuscular mycorrhizae on growth of in vitro propagated pistacia integerrima. Acta Horticulture. 227: 441-443

Smith, S. E. and Read, D. J. (1997).
Mycorrhizal symbiosis. Cambridge, UK: Academic Press.

Wang, H., Parent, S., Gosselin, A. and Desjardins, Y. (1993). Vesiculararbuscular Mycorrhizal Peat-based Substrates Enhance Symbiosis Establishment and Growth of Three Micropropagated Species. Journal of American Society for Horticultural. Scince. 118: 896-901.

Yano-Melo, A. M., Leonor, M., Orivaldo José Saggin Júnior, Lima-Filho, J. M. and Melo, N. F. (1999). Effect of arbuscular mycorrhizal fungi on the acclimatization of micropropagated banana plantlets. Mycorrhiza. 9: 119123.

\section{How to cite this article:}

Uzma Mehraj, Sapna Panwar, Kanwar Pal Singh, Namita and Seema Sangwan. 2019. Effect of VAM on ex vitro Hardening of Doubled Haploid Line of Marigold (Tagetes erecta L.) Variety Local Orange. Int.J.Curr.Microbiol.App.Sci. 8(01): 1393-1403. doi: https://doi.org/10.20546/ijcmas.2019.801.148 